Journal of Teachers of English

Volume 5 No. 2, 2020

e-ISSN: $2548-6810$

\title{
THE EFFECT OF WHOLE BRAIN TEACHING METHOD TOWARD STUDENTS VOCABULARY ACHIEVEMENT OF SEVENTH GRADE AT SMP NEGERI 17 KEC. KEP. MASALOKA RAYA
}

\author{
Nirmala ${ }^{1}$, La Ode Nggawu ${ }^{2}$, Wa Ode Fatmawati ${ }^{3}$. \\ Nirmalamala149@gmail.com \\ ${ }^{1}$ Halu Oleo University, Indonesia.
}

\begin{tabular}{l} 
ARTICLE INFO \\
\hline Keywords: \\
Whole Brain Teaching \\
Method, vocabulary \\
achievement \\
How to cite: \\
DOI:
\end{tabular}

\begin{abstract}
The researcher investigated the effect of whole brain teaching method toward students vocabulary achievement at SMPN 17 Kec. Kep Masaloka Raya. The design of the research was pre-experimental design. The population of the research were all the seventh grade students of SMPN $17 \mathrm{Kec}$. Kep. Masalaoka Raya. In taking sample the researcher using purposive sampling then the researcher chose class VII A of SMPN 17 Kec. Kep. Masaloka Raya which are consist of 28 students. The research used three kinds of vocabulary instrument. The instrument were fill the blank, match word, and rearrange word. The vocabularies test consist of 10 items each test. The test complied by the researcher based on the material in English book in the seventh grade, entitled Ring of The bells. In this research, quantitative data was collected and analyzed by using paired sample $t$ test in SPSS 16.0. the result of the analysis show that the probability value $(p)$ was lower than alpha value $(\alpha)$ at the level significant $95 \%(0.000<0.05)$. This finding result justified that there was significant differences between students vocabulary score on pretest and post-test or there was significant effect of applying whole brain teaching method toward student vocabulary achievement at seventh grade of SMPN 17 Kec. Kep. Masaloka Raya after treatment. The result prove that the hypothesis of the research was accepted $\mathrm{H}_{1}$ but $\mathrm{H}_{0}$ was rejected.
\end{abstract}

\section{INTRODUCTION}

The teaching and learning process in English language classroom, especially in secondary school, has been focusing on the mastery of the four skill,namely listening, speaking,reading, and writing. That is why there have been many attempt applied to ensure those four skills can be actuated in the student daily learning. However, the four skills that have been mentioned, will difficult to mastering by student's without recognize many vocabularies. 
There is one method that can be used in teaching vocabulary, this method is called Whole Brain Teaching. Macias, A. \& Macias, B. (2013:178) stated that Whole Brain Teaching is method that is used to get students involvement with well-structured instruction and enjoyable order. Whole brain teaching includes valuable tools such as memory gestures to cover each material. This method not only has class management techniques that are packaged in a fun way, but also keeps the student brain active when the learning process takes place.

Therefore, by using the Whole Brain Teaching method, students are expected to remain focus on the material that the teacher convey and their brain are stimulated to be able to work optimally, so that the information are delivered by the teacher will be easy to digest and not easy to forget. Then the teaching and learning activities take place in a fun, disciplined and tightly organized atmosphere, because there are several rules in the classroom, so that the learning objectives that have been made and set are expected to be achieved with maximum results.

Based on the explanation above, the writer formulated the research question to be answered in this study is:

Is there any significant effect of applying Whole Brain Teaching method toward students English vocabulary achievement of seventh grade at SMPN $17 \mathrm{Kec}$. Kep. Masaloka Raya"?

\section{RESEARCH METHODOLOGY}

This research was quantitative research. Then, the researcher used pre experimental design. The aims of this design was to find out whether or not any significant effect of applying whole brain teaching method toward students' vocabulary achievement of seventh grade, and the research was conducted in SMPN17 Kec. Kep. Masaloka Raya, on Thurday, $28^{\text {th }}$ March 2019. Students of VII A were used as samples.

The instrument of this study is vocabulary test. The test consist of 30 numbers of rearrange and matching the words. The topic of the test were about noun, and adjective consist of Profession, The Animal and Their Activities, Things and their function ( Things in the classroom classroom and in the house). The test was given in pre-test and post-test to know how far students' vocabulary before and after getting treatment. 
The data of this study was analyzed quantitatively. In this study, the researcher used the descriptive and inferential statistic for analyzing the data. Descriptive statistics was used to know the differences result before and after a treatment. By used descriptive statistic, the researcher showed how to present the data by using tables, frequency, diagram, and explanation about mean, derivation standard, maximum and minimum score, and range score.

Inferential statistic was used to test the hypothesis by used t-test. It was to know the significant effect of applying whole brain teaching method towards students' vocabulary achievement at seventh grade, the researcher used Paired sample T-test by used SPSS application version 16.0.

\section{FINDINGS}

\section{Comparisons of Students' Score on the Pre-Test and Post-Test in Experimental Class}

\begin{tabular}{|c|c|c|c|c|c|}
\hline $\begin{array}{c}\text { Classificatio } \\
\mathbf{n}\end{array}$ & Range & \multicolumn{2}{|c|}{ Pretest } & \multicolumn{2}{c|}{ Post-test } \\
\cline { 3 - 6 } & & Frequency & Percentage & Frequency & $\begin{array}{c}\text { Percen } \\
\text { tage }\end{array}$ \\
\hline Very High & $\mathbf{8 6 - 1 0 0}$ & 0 & $0 \%$ & 0 & $0 \%$ \\
\hline High & $\mathbf{7 0 - 8 5}$ & 0 & $0 \%$ & 10 & $36 \%$ \\
\hline Moderate & $\mathbf{5 6 - 6 9}$ & 3 & $11 \%$ & 5 & $18 \%$ \\
\hline Low & $\mathbf{4 1 - 5 5}$ & 8 & $28 \%$ & 11 & $39 \%$ \\
\hline Very Low & $\mathbf{0 - 4 0}$ & 17 & $61 \%$ & 2 & $7 \%$ \\
\hline & $\sum$ & $\mathbf{2 8}$ & $\mathbf{1 0 0} \%$ & $\mathbf{2 8}$ & $\mathbf{1 0 0} \%$ \\
\hline
\end{tabular}

The table above was about the comparison of students' score on the pre-test and post-test in experimental class. It showed that the students who got very high criteria in post test and pre test was 0 students $(0 \%)$, students who got high criteria in post test were 10 students $(36 \%)$, while in pre test was 0 students $(0 \%)$. Students who got moderate criteria in post test were 5 students $(18 \%$ ), while in pre test were 3 students (11\%). Students who got low criteria in post test were 11 students (39\%), while in pre test were 14 students (28\%), and students who got very low criteria in post test was 2 students (7\%), while in pre test were 17 students $(61 \%)$.

\section{DISCUSSION}

In this research, the researcher used Whole Brain Teaching method as an alternative solution to help students to overcome their difficulty in learning vocabulary. The use of Whole Brain Teaching helps to improve the students English vocabulary 
achievement because it provides relax and enjoyable situation in teaching learning process. It makes students can learning with their unconscious.

Techniques in Whole Brain Teaching method increase students' enthusiasm to be more active in learning process. They can tell a lot about the materials with their friends. It made them feel free to express something because they do not need to talk with the teacher, some of the students feel so nervous in talking with teacher. Macias, et al. (2013) said that whole brain teaching is method that is used to get students involvement with well-structured instruction and enjoyable order. Whole brain teaching includes valuable tools such as memory gestures to cover each material. In the beginning of the process, the researcher already had a deal with the students about the rule of the class during learning English.

Besides that, it was also found that students really enjoyed the process because Whole Brain Teaching also made them learn with their body language. It is easy for the students to memorize what the teacher had said because they say something and move their body. Young learners are as children really enjoy that activity. They do not only listen but also do in real activity.

In this research, first, the researcher administered the pre-test. The pre-test was given on Thursday, March $28^{\text {th }}, 2019$. The result showed that the mean score of the pre-test was 38.00 .

In teaching and learning process, first, the teacher started with tells the students about "Class Yes" technique. It was easy for students to follow this technique because every time the teacher says "Class", they only need to answer "Yes" with the same tone the teacher did. Then, the teacher explain about "Five Classroom Rules" technique. The teacher found that the students still confused about the rules that was made by the teacher. It was their first time learning English with that situation. They have to talk in English during the teaching learning English before it, they were rare using English in the class. Many of students did not know what to do in the beginning of the class. It made them need more time to understand what teacher has said. Therefore teacher re-explain by speak in Bahasa. After telling them about "Class-Yes" and "Five Classroom Rules" the teacher draw boards score on the white boards. Furthermore teacher explained about the kinds of professions, animals and their activity, and thing, and then the teacher showed some pictures about profession, animal and things, and 
then asked students read dialog on the text book that had been shared by the teacher. Then teacher reads dialog and asked to repeat the pronunciation words that has been examplified. Next, the teacher asked students to collect vocabulary about noun verb and adjective from the dialogue and the pictures had been shown before and teacher write them on white board. Then, the teacher move into telling them to "Teach-Okay" the vocabulary that had been written on white board. This technique asked the students to retell/re-explain the materials to their friends. The condition of the class being so crowded in this part because all of the students were talking. Teacher's role was really needed in this condition. Teacher has to control the class by walking around the class and watch what the students are talking about. It also helped the students who felt difficult in doing this technique. after the "teach okay" session goes well, teacher reach the students attention by applying "class-yes" technique. Next, teacher gave instruction to do "switch" technique, where students exchange their role to explain the vocabulary that they already knew with their peers. Finally teacher asked five students to mention the vocabulary that they have learned during the course at least 10 vocabularies.

Furthermore, teacher gave worksheet for each student to know students' understanding about the material that has been learned. The form to know their ability in understanding was related to the material had been given by the teacher. After that in last part, teacher and students are conclude about the vocabulary about the lesson and teacher gave value to the performance in following instruction from the teacher during the learning process on the score board.

Thombury (2000), says that teaching vocabulary is a key factor that involves teaching three fundamental steps such as presenting, practicing, and producing orders to have an effective vocabulary learning process. And Tripsa (2014) stated that whole brain teaching is a method of teaching which combines movement, making gestures, teaching each other, group work and immediate feedback. So by applying Whole brain teaching method, students are possible to develop vocabulary and recognize more new words, because the new vocabulary they find is taught to their peers, and it is done two to three times by "teach okay" and "switch" technique.

In teaching and learning processes, students showed high participation and motivation while learning processes were begun. They can be fun and enjoyed in the class but still follow the rules class so they also remain focused on teacher instruction. 
This is can be seen from the high enthusiasm of students when doing the "teach okay" and "switch" technique, and during the learning process they always follow the rules class to get a mark on the scoreboard, and they was really happy when obtained that mark. Regarding this finding, researchers believe that whole brain teaching method as a method of teaching can ensure the students' vocabulary achievement. This concept was supported by data found in statistical analysis.

The last, the researcher gave the post-test. The post-test was given on Monday April $11^{\text {th }}, 2019$. The result showed that the mean score of post test is 60.03 . Then, the researcher computed the $t$-value and the effect size. The result of $t_{\text {count }}$ is 9.41 . the $t_{\text {table }}$ is obtained with $t$ distribution at the level significance of $95 \%(\alpha=0.05)$ and the degree of freedom $(\mathrm{d} f)$ was 27 , so that $\mathrm{t}_{\text {table was }}(27 ; 0.05)=2.052$. it means that $\mathrm{t}_{\text {count }}$ was higher than $t_{\text {table }}(9.41>2.052)$. The result of the effect size is 0.75 and it is categorized as 'medium effect'. From the result, the researcher concludes that the use of Whole Brain Teaching method is effective in improving the students vocabulary achievement to the seventh grade of SMPN 17 Kec.Kep.Masaloka Raya 2018/2019.

\section{CONCLUSION AND RECOMMENDATION}

\section{Conclusion}

Based on finding of this research, the researcher concludes that there was a significant effect of whole brain teaching method the students vocabulary achievement at grade VII A of SMPN $17 \mathrm{Kec}$, Kep. Masaloka Raya. It is indicated by the result of hypothesis testing which proved that $\mathrm{t}_{\text {test }}=9.41$ was Higher that $\mathrm{t}$-table $=2.056$. then the probability $(p)$ value (sig 2 tailed) at significant level $95 \%(\alpha=0.05)$ was 0.00 . the probability value $(p)$ was smaller than alpha $(\alpha)(0.00<0.05)$. It means that there was a significant effect of applying whole brain teaching method on the students vocabulary achievement of seventh grade at SMP Negeri $17 \mathrm{Kec}$. Kep. Masaloka. So that, the hypothesis of the research was accepted $\mathrm{H}_{1}$ but $\mathrm{H}_{0}$ was rejected.

\section{Suggestion and Recommendation}

After conducting this research, the researcher though and considered several recommendation to the next researcher. They are: 
1. The researcher suggested to the English teacher to apply Whole Brain Teaching method in teaching English vocabulary, because the method can improve students vocabulary score.

2. This research applied pre-experimental design with using was class only, it is possible to apply different design such as action research and true experimental design in order that the result of the research can be more clearly explained

3. The subject of this research was Junior High school students at first grade. It is possible to conduct the further study in different level or school because different population and different condition of the research will diverse result.

\section{REFERENCES}

Biffle, C.(2013). Whole Brain Teaching for challenging kids. Whole brain teaching: A world leader in brain based learning.p.7.

Macias, A. \& Macias, B.(2013) Whole brain teaching and learning research. In C. Biffle (Ed.), Whole Brain Teaching for Challenging Kids (pp. 178-189). NA: Whole Brain Teaching.

Thombury, Scott.(2000). How to teach Vocabulary. England:Longman I A/L/F.

Tripsa, M.(2014). Whole Brain Teaching. Technique Teachers Tricks. Retrieved from http://ashleytipton.weebly.com/whole-brain-teaching.html. 